\title{
When gender bumps into health and safety training: working conditions, readings and challenges drawn from a case study in an industrial chemicals company
}

\author{
Ricardo Vasconcelos ${ }^{\mathrm{a}^{*}}$, Sandra Teixeira ${ }^{\mathrm{b},}$ Joana Castelhano $^{\mathrm{a}}$ and Marianne Lacomblez ${ }^{\mathrm{a}}$ \\ ${ }^{\mathrm{a}}$ Centro de Psicologia da Universidade do Porto, Faculdade de Psicologia e de Ciências da Educação, Rua \\ Alfredo Allen, 4200-135 Porto, Portugal \\ ${ }^{\mathrm{b}}$ Faculdade de Psicologia e de Ciências da Educação da Universidade do Porto, Rua Alfredo Allen, 4200-135 \\ Porto, Portugal
}

\begin{abstract}
Health, safety and environmental issues are at present a social concern and an increasingly referred topic in the so called gender studies. This paper focuses on the relations between training, gender and risk perception in an industrial chemicals company, in Portugal, characterized by a mainly male population and by the presence of high occupational and environmental hazards. After characterizing the company and the training project that started up this reflection, the paper presents the reasons for its focus on gender followed by the essential methodological explanations: 14 interviews were made with male and female workers from the company; their content was transcribed from the audio recordings and it was systematically analyzed. A gender-attentive socio demographic analysis was also undertaken. Although at the beginning the company did not consider the gender issues as a problem nor was it the central topic of the training, which focused on the prevention of occupational and environmental hazards, the results reveal that the gender factor brought to light some working conditions, which so far have not been properly discussed within the group meetings. As a consequence, there is now room for the transformation of the representations on those working conditions.
\end{abstract}

Keywords: health and safety, prevention, training, women and work

\section{Introduction}

The last decades have been characterized by the massive entry of women into the labor market. However, it is clear that their professional integration did not proceed uniformly. In fact, even today there are occupations traditionally regarded as male or female, entrenched in professional activities seen as more suitable for men or women. Therefore, according to Grönkvist \& Lagerlöf [5], sex segregation in the labor market is at the same time horizontal because it compels women mainly to clerical and care jobs, whereas men are responsible for technical functions related to industrial production - and ver- tical - making it difficult for women to access positions of leadership and direction, where we rarely see them.

Simultaneously to this upward trend in the representation of women in the active population, there is a growing concern towards issues of safety and occupational health, although one of the main shortcomings of the EU Directives on health at work is the sexual division of labor [9]. As Vogel stated [14], if, on the one hand, sex segregation in the professional context and the subsequent unequal distribution of work involves different risks for both sexes, on the other hand, the denial of both the risks and

*Corresponding author. E-mail: ricardo@fpce.up.pt 
the damages to health is mostly based on the sex distribution of work.

The gender dimension is incorporated in day-today work, crossing the organizational practices, the labor market dynamics or the choices made by the social institutions. Nevertheless, exploring the meaning of gender within the scientific investigation turns out to be a considerable challenge, both from a theoretical and methodological point of view [6].

In the study reported in this paper, taking the dimension gender into consideration came as a result of the implementation of a participatory training project based on the "Matriosca" model [11]; that project aimed the promotion of industrial and environmental safety in a Portuguese industrial chemicals company. Despite the fact that the initial request, which originated the intervention, did not include gender as subject of debate, let alone of transformation, the truth is that the "non-issue" assumed progressively a permanent role in the approach of the employees' behaviors and attitudes towards hazards [12]. Given this overall picture, this paper intends to analyze the relations between training, gender and risk perception in a company whose population is essentially male.

In order to better understand the role that the "gender filter" plays in the perception of risk related to the company's activity, several male and female employees from different functions and levels of responsibility were interviewed while the training project was being implemented.

Based on the results of this study it will then be possible to assess the importance and the challenges faced when the dimension gender is taken into consideration for health and safety training, evaluation and transformation of risk perception and also improvement of working conditions.

\section{The "Matriosca" project: training and work transformation in a single process}

We will not address in detail the training project in question. A detailed description can be found, for instance, in Vasconcelos, Fortuna, Teixeira and Lacomblez [12] and Vasconcelos, Silva, Pinto and Duarte [13].

Briefly, the training project combined individual moments of on-the-job guided analysis and in-class discussion moments.

The training groups of 10 to 15 people included mainly plant operators (production and mainten- ance), but also first line managers and members from other support services (safety, hygiene and environment, logistics, automation and control, human resources, commercial, etc.). Given the functional profile of the training groups and the company's socio-demographic characteristics, the participants in the 10 training groups sum 115 people, 103 male and 12 female.

During the in-class discussion sessions it became clear that there were on-going processes of rendering the risks common and natural, namely in terms of the effects of exposure to certain chemicals. This finding made it necessary to search for training strategies which could help on its deconstruction. At this stage the "gender factor" revealed its pertinence. The gender dimension ended up being a powerful instrument to confront the participants with the noxiousness they are daily exposed to, by entering the protective bubble that masculinity supposedly and even unconsciously provides the male employees [12].

The verbalizations found throughout the training, for example: "this is not a chocolate industrial plant" or "previously the work was far worse", seem to be related to the depreciation of the risks inherent to the company's activity. It is just as if there is some difficulty in admitting weakness or fear associated to the need to adopt dangerous behaviors in terms of health; such behaviors are required in order to develop an heterosexual male identity [1]. Still, when these men are asked about the possibility of a woman perform their current functions in the future, they immediately point out risks and laborious tasks to which the women would inevitably be exposed to. The "introduction" of the female element unlocks the situation. It is confirmed that the general consciousness of risk coexists with the internalization of social norms which make those risks bearable.

In this type of occupations, traditionally considered male, where the proportion of men is at least three to one [4], the workers end up accepting, almost without any questioning, the norms of laborious work, associating those norms to principles of virility and valuing them as part of the job's identity and their own professional identity [10].

Rendering the risks common or natural can also be interpreted through the notion of "defensive strategies", defined by the Psychodynamics of work (Dejours, 1980, cit in [2]) to explain a certain way of fighting pain at work. Such defensive strategies, however, can jeopardize the training on hygiene and safety at work [1]. 
On the other hand, the elevation of virility and all its stereotypes within working environments defined as masculine, may work as a true selection among workers [14]. Here it is recognizable Kergoat's idea [7] that anything is likely to be transformed when jobs defined largely in masculine start integrating women.

As Lacomblez points out [8] (p.39): "Inserting women in predominantly masculine professional environments seems to enable other explanations for certain aspects of work situations that deserve debates and improvements". Consequently, taking the gender dimension into consideration makes it possible to ask new questions and contributes to a better visibility and understanding about the work and job conditions that so often distinguish men and women [3].

This finding actually arouse interest for a new field of investigation and potential intervention in the company (despite the fact that the gender dimension was a "non-issue" at the beginning): to try to better understand this apparent "idéologie défensive (de genre) et de métier" which, according to Molinier (2000, cit in [2]), consists in using the so called masculinity strategies, culminating the in the denial of danger.

\subsection{Company description}

The company where the training project was implemented is located in Portugal and operates as a two-plant company after merger. One of the plants has as main process the production of aniline, a substance with several industrial purposes. The other one specialized on the production of chlorine and hydrogen using a process called electrolysis. Nowadays the company has around 189 employees, divided by the two plants.

The production works continuously, divided into rotating eight-hour shifts. In the case of the aniline plant, each sub-installation (mononitrobenzene$\mathrm{MNB}$, aniline, nitric acid, sulphanilic acid) has two operators per shift: one is responsible for the panel (he coordinates the productive process, which is quite automated, using a computer panel) and the other is responsible for the intervention "outside" the control room (responsible for monitoring the facilities in loco, for the manual operation of valves and for sampling). There are also operators of effluents, sulphanilic acid, boilers and tank filling (responsible for supplying tanks with benzene to produce MNB and with ammoniac to produce nitric acid). In terms of other support services with no responsibility over the production, the laboratory analysts are the only ones present in the plant for 24 hours. The maintenance obeys office hours, i.e., $9 \mathrm{am}-17 \mathrm{pm}$, but it is 24 hours on-call.

As far as the chlorine plant is concerned, there is a difference in terms of work organization. The workers are not divided per installation, but per stage of the production process. Each stage is entitled panel 1, panel 2 and panel 3. For each panel there is one panel operator and one external operator.

Given its production process, the company's safety policy is focused on industrial incidents which imply leaks or spills of chemicals because in the facilities there are several types of substances: carcinogens (benzene), highly corrosive (sulphanilic acid), highly flammable (hydrogen) and toxic (chlorine). One safety incident in this company can go beyond its walls and threaten not only the workers, but the entire community and the environment where it is located. There are few work accidents reported; nevertheless, personal safety is always a sensitive issue for the company's activity, obviously.

\subsection{Socio-demographic characterization}

The company's age structure is stable over the last few years; most workers are 35 to 59 years old and over half of them have at least 20 years of seniority in the company.

As previously stated, the vast majority of the workers are male, only 26 are female; in addition, men and women perform different activities. 

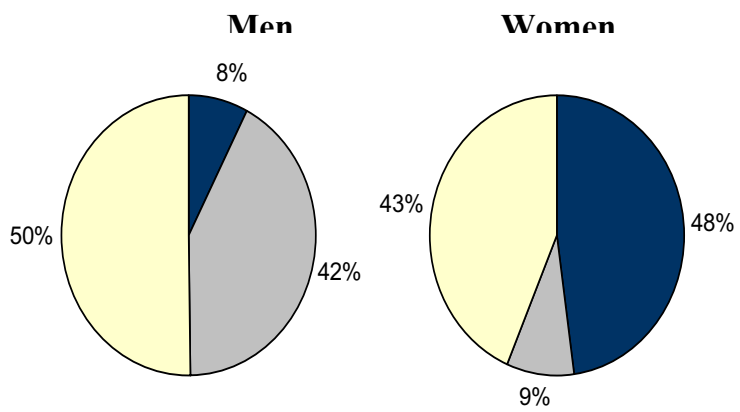

Office $\square$ Outdoors $\square$ Indoors

Figure 1 - Type of work performed by men and women, throughout 2009

It was possible to check that throughout 2009 (cf. Figure 1) there were more men than women performing outdoor functions, whereas in terms of office functions happens exactly the opposite since almost half of the female workers can be found here. Considering the indoor functions, women split into laboratory functions and research and development functions, while most men provide direct support to the production.

It is also worth underlining that working in the plant obliges to an exposure to chemicals, to bad weather conditions and to higher physical efforts; on the other hand, in the office the work is less severe in terms of physical effort and exposure to danger. Clearly, the different jobs performed by men and women come, naturally, with different risks as well.

\section{Methodology}

14 interviews were conducted, recorded in audio and fully transcribed. The interview script included a set of topics and questions to be discussed, allowing a pre-orientation in favor of the interviewer and, at the same time, offering the interviewee the freedom to express the ideas he/she considers fit. The topics and the questions to explore aim to represent, generally, the objectives we intend to study.

The interviews took place in the company's facilities, specifically, in the participants' workplace and at a previously scheduled timetable. Although we registered a significant variance in the length of the interviews, they were planned for 20 minutes, so to avoid disorders in the company's production process, as they took place during the working period.

From the universe of employees, we tried to interview those with different functions and distinct levels of responsibility, in order to obtain comparisons which allow an easier understanding over the representations of risk related to the activity, but also over the relation between risk perception in the company and the gender dimension. Table 1 shows the participants' characterization.

The analysis of the results is the starting point to try to comprehend the implications of the gender dimension in the training on hygiene and safety at work, in the assessment and transformation of risk perception and, possibly, in the improvement of the working conditions.

Table 1

Participants' characterization

\begin{tabular}{cccc}
\hline ID & Sex & Function & Age \\
\hline 1 & Female & Process engineer & 41 \\
\hline 2 & Male & Laboratory analyst & 39 \\
\hline 3 & Male & Process engineer & 29 \\
\hline 4 & Female & Human Resources technician & 34 \\
\hline 5 & Male & Panel operator & 27 \\
\hline 6 & Male & External operator \\
\hline 7 & Female & Quality, Safety and Environment Department \\
\hline 8 & Female & Laboratory analyst \\
\hline 9 & Female & Administrative assistant \\
\hline 10 & Male & Shift manager \\
\hline 11 & Male & External operator \\
\hline 12 & Male & Human resources manager \\
\hline 13 & Female & Marketing technician \\
\hline 14 & Male & Process engineer
\end{tabular}




\subsection{Content analysis}

The interviews' content analysis was carried out using the software NVivo, which allowed data systematization. After transcribing the whole interviews, this software allowed the organization of the data in different categories decided according to the organization and classification of the information. The categories were decided based on bottom-up logic and the subjects were offered by the participants' speech. The codification of the categories was not mutually exclusive, so one verbalization can be included in more than one category.

Seven main categories were defined and are presented hereafter: Characterization of Typical Female Job (characteristics of the job which the interviewees associate as being typically female); Characterization of Typical Male Job (characteristics of the job which the interviewees associate as being typically male); Noxiousness Evolution (how the characteristics related to the activity evolve, according to the interviewees); Perception of Noxiousness (whether the interviewees perceive noxiousness in the company as being common to both sexes or whether it differs between men and women); Justification for the $\mathrm{Nu}$ merical Imbalance (in the opinion of the interviewees, which are the reasons for the imbalance between men and women at the company); Evolution of Expectations (perception of the participants towards the way the company's numerical imbalance can progress) and at last Justification for the Higher Number of Accidents with men (reasons that according to the participants explain why men suffer more accidents than women).

\section{Results and discussion}

The primary analysis to the collected data, which will be further explored and presented at the Symposium, confirmed that the male workers tend to render the risks "natural". But the "naturalization" processes are part of a quite ambivalent scenario, which leads those workers, at the same time, to depreciate the risks - ignoring some of its aspects; and, on the other hand, to the risks' global valorization, connecting them to a typically masculine activity.

Regarding the first axis of this scenario, it is at this stage worth mentioning that the working hours correspond to the top-ranked motive to explain the numerical imbalance between men and women. Now, during the training sessions, this aspect had never been discussed, nor associated with the notion of "risk". When the participants consider the possibility of including women in this activity, they cannot but say that unconditional availability towards all working hours is not evident, because it is necessary to plan them according to the personal and family life [4]. Still, they do so without evoking the risks related to this type of work-time organization - and those risks are particularly their concern as they correspond to the characteristics of the conditions in which they developed their professional activity over the years.

On the other hand, the physical roughness and the exposure to noxiousness are the main characteristics used by the interviewees to qualify the masculine work, the most representative in the company.

In fact, the exclusive admission of men in the occupation supported the construction of identity references strongly based on the enhancement of the abilities to deal with an activity whose unsafety has always been obvious for coworkers, superiors and nearby inhabitants. This was the basis for the development of a strong solidarity in the working group, rooted in the valorization and sharing of a laborious job, and related to virility.

Actually, the interviewees unanimously state a perception of improvement in the safety conditions, the decrease in the physical demand and a globally positive evolution of the laborious work in the company. But this perception has not led them to consider it a favourable factor towards the evolution of gender inequality.

The dimensions invoked the most to explain the numerical imbalance between men and women are "outside" the heart of the activity: regarding the working hours, as previously explained; or even regarding the lack of facilities, namely female toilets and locker rooms, the cost of building those facilities or, generally speaking, regarding the "company strategy".

During the training process it became fairly clear that there is very little opening for a reflection on gender issues. This theme was not included in the company's initial request, it does not assume a prominent role for the company and the necessary investment to mitigate certain inequalities competes directly with other "safety" interventions prompted by the training intervention. As a result, the theme of gender became eventually imposed by the trainers. The gender is only addressed due to the fact that the interlocutors consider it to be strategically pertinent to the goal underlying the training on prevention and safety. The issues on gender inequality keep having 
no room in this type of intervention. Even so, they are a determinant factor in terms of reflection and confrontation with risks, which had not been mentioned during the group discussion, particularly physical and psychosocial risks related to the working hours.

\section{Conclusions}

Despite the fact that this text only highlights the preliminary results of the exploratory study, we can assume that the gender dimension emerges as an important tool for the training, namely, because it made it possible to confer visibility to working conditions, which so far have never been given serious thought in the discussion groups. Still, treating the gender issue in the company where the study was conducted competes with the solution of other issues, which came forward as problems under the scope of the training in prevention and these last issues are actually the ultimate goal of the training. Now, the trainer (who is simultaneously a social scientist) faces a dilemma very difficult to solve.

The women, who face so many difficulties to enter the company's production sector, end up managing to do so, even though symbolically, through the training door, particularly thanks to the discussion of certain themes, like the working hours issue, neglected up to this point, that become part of the debate and the reflection on safety and health promotion in an industrial context.

\section{References}

[1] L. Artazcoz, C. Borrell, I. Corès, V. Escribà-Agüir and L. Cascant, Occupational epidemiology and work related inequalities in health: a gender perspective for two complementary approaches to work and health research, Journal of Epidemiology and Community Health 61, suppl. 2, (2007), 39-45.

[2] P. Bouffartigue and J. Pendariès, Virilité, métier et rapport aux risques professionnels: le cas de travailleurs de la soustraitance, Pistes 12 (3) (2010).

[3] J. Castelhano and S.Nogueira, Género e trabalho. O processo de inserção feminina em profissões tradicionalmente masculinas. Relatório final, Centro de Psicologia da Universidade do Porto (não publicado), Porto, 2011.

[4] Diário da República, I-B série - N. ${ }^{\circ} 296$ - Portaria n. ${ }^{\circ} 1212$ 2000 de 26 de Dezembro de 2000.

[5] L. Grönkvist and E. Lagerlöf, A saúde e o trabalho das mulheres europeias, in: Compreender o Trabalho das Mulheres para o Transformar, K. Messing, ed., CITE, Lisboa, 200, pp. 35-50.

[6] A. Härenstam, Exploring gender, work and living conditions and health - suggestions for contextual and comprehensive approaches, Scandinavian Journal of Work, Environment \& Health 35 (2) (2009), 127-133.

[7] D. Kergoat, Des hommes, des femmes et du travail, Éducation Permanente 116 (1993), 133-139.

[8] M. Lacomblez, A feminização dos meios de trabalho definidos em masculinidade : debates de normas e desenvolvimento, Laboreal, 4 (1) (2008), 39-45.

[9] M. Sapir, Prefácio, in: Compreender o Trabalho das Mulheres para o Transformar, K. Messing, ed., CITE, Lisboa, 2000, p. 5.

[10] L. Scheller, Les bus ont-ils un sexe ? Les femmes machinistes : approche psychodynamique de la division sexuelle du travail à la RATP., RATP, Paris, 1996.

[11] R. Vasconcelos, O papel do psicólogo do trabalho e a tripolaridade dinâmica dos processos de transformação: contributo para a promoção da segurança e saúde no trabalho. Dissertação de doutoramento, Universidade do Porto, 2008.

[12] R. Vasconcelos, P. Fortuna, S. Teixeira and M. Lacomblez, Formation-action participative pour la sécurité industrielle et environnementale dans une entreprise - définie au masculin. Actes SELF 2011: L'ergonomie à la croisée des risques, SELF, Paris, 2011.

[13] R. Vasconcelos, D. Silva, R. Pinto and S. Duarte, Evaluating work and training within an intercommunicating process of change: reflections drawn from a case study on a chemicals industrial company in Portugal. Proceedings IEA 2012 Congress: Designing a sustainable future, International Ergonomics Association, Recife, 2012 (in press).

[14] L. Vogel, Um contributo do Quebeque para um debate indispensável ao movimento sindical na Europa, in: Compreender o Trabalho das Mulheres para o Transformar, K. Messing, ed., CITE, Lisboa, 2000, pp. 9-33. 